\title{
The CD40 agonistic monoclonal antibody APX005M has potent immune stimulatory capabilities
}

\author{
Pia Bjorck, Erin Filbert, Yongke Zhang, Xiaodong Yang, Ovid Trifan* \\ From 30th Annual Meeting and Associated Programs of the Society for Immunotherapy of Cancer (SITC 2015) \\ National Harbor, MD, USA. 4-8 November 2015
}

The co-stimulatory receptor $\mathrm{CD} 40$ is a member of the tumor necrosis factor receptor (TNFR) superfamily and plays an important role in the control and regulation of immune activation, especially in crosstalk between $\mathrm{T}$ cells and antigen presenting cells (APCs). The natural ligand for CD40 (CD40L, CD154) is expressed on activated T cells and provides a major component of $\mathrm{T}$ cell "help" for the immune response. Agonistic CD40 antibodies can substitute for the function of CD154 on T cells to boost immunity by stimulating antigen presentation and co-stimulation to $\mathrm{T}$ cells and have been shown to be potent boosters of anti-tumor immune responses. Anti-CD40 can directly inhibit tumor growth in CD40 expressing tumor cells.

APX005M is a humanized IgG1 monoclonal antibody that binds CD40 with high affinity and blocks the binding of CD40 to CD40L. APX005M activates dendritic cells, $B$ cells and monocytes, and promotes antigen-specific $\mathrm{T}$ cell responses. APX005M demonstrates potent antitumor activity via ADCC and induction of apoptosis in CD40 expressing tumor cells. In comparison with other CD40 agonistic antibodies such as CP-870, 893 and SGN40 analogs, APX005M has more potent CD40 agonistic effects and antibody effector function.

Published: 4 November 2015

doi:10.1186/2051-1426-3-S2-P198

Cite this article as: Bjorck et al:: The CD40 agonistic monoclonal antibody

APX005M has potent immune stimulatory capabilities. Journal for

ImmunoTherapy of Cancer 2015 3(Suppl 2):P198.
Submit your next manuscript to BioMed Central and take full advantage of:

- Convenient online submission

- Thorough peer review

- No space constraints or color figure charges

- Immediate publication on acceptance

- Inclusion in PubMed, CAS, Scopus and Google Scholar

- Research which is freely available for redistribution 